\title{
Articles
}

\section{Determining the "Private Law" Nature: A Comparison Between Customary State Practice and Turkish Court Rulings}

\author{
By Yasir Gökçe*
}

\begin{abstract}
This Article uses a combination of doctrinal and comparative analyses to elucidate the most widely-used criteria according to which courts characterize an act as having a private-law nature. Further, this Article identifies the extent to which the Turkish State practice has embraced those criteria. To that end, this Article extracts two such widely-used criteria from patterns in customary State practice. In the end, the Article points out the extent to which those criteria are prevalent throughout the Turkish court rulings and concludes that Turkish caselaw is generally in alignment with the customary State practice in terms of the criteria used to determine a State act's private-law nature.
\end{abstract}

\footnotetext{
* Former Diplomat at the Ministry of Foreign Affairs of the Republic of Turkey and former Research Assistant at the Harvard University; MPA (J.F. Kennedy School of Government at Harvard University), LLM (Ankara Univ.), LL.B.(Bilkent Univ.) The author may be contacted at: gokceyasir@gmail.com / yasir_gokce@hks16.harvard.edu.
} 


\section{A. Introduction}

Under the law of state immunity, "the private-law act"-expressed as acta jure gestionis in Latin-refers to an exception to state immunity that serves as the benchmark for determining whether a State is subject to the jurisdiction of a foreign domestic court. ${ }^{1}$ Once a court establishes the "private-law" nature of an act, it may deny immunity to a foreign State without jurisdictional inconveniences. This emphasizes that the crux of the matter in such cases is how an act is to be properly characterized as having a private-law nature. Indeed, the shift from absolute immunity to the restrictive doctrine can be depicted as States oscillating between the purpose test and the nature test, with the balance eventually tiping in favor of the latter. ${ }^{2}$

States with the restrictive doctrine have introduced their own commercial or private law exceptions into their legislation and caselaw. ${ }^{3}$ Nevertheless, because courts lack all-encompassing and clear cut criteria for determining the private-law nature of an act, it is hard to formulate this exception in a way that is acceptable to all. Courts are thus left to render such determinations in an ad hoc manner.

This Article uses a combination of doctrinal and comparative analyses to elucidate the most widely-used criteria for characterizing private law acts as such, and also to identify the extent to which those criteria have been embraced in practice by the Turkish State. To that end, Section B delves into actual state practice in the form of legislation and court rulings to identify the patterns by which States determine the private-law nature of an act. This Article extracts two widely-used criteria from patterns in customary state practice with respect to the private-law exception to immunity. The justifications and reasoning given by States while determining the private-law nature of an act signal a growing convergence of State practice in the criteria that courts employ to characterize an act as having a private-law nature.

To make sense of the shifts in Turkey's approach to immunity, it is important to uncover the motivations and considerations underlying those shifts. Sections $C$ and D accomplish this by examining both the immunity question during the Ottoman era when the Capitulations were

\footnotetext{
${ }^{1}$ Hazel Fox \& Philippa WebB, The Law of State Immunity 213 (3d ed. 2013).

${ }^{2} / d$.

${ }^{3}$ See, e.g., State Immunity Act 1978, c. 33 (UK); Foreign Sovereign Immunities Act of 1976, 28 U.S.C. §§ 1330, 1332, 1391(f), 1441(d), 1602-11; Gaikoku-tō ni taisuru wagakuni no minji saiban-ken ni kansuru hōritsu [Act on the Civil Jurisdiction of Japan with Respect to a Foreign State, etc.], Law No. 24 of 2009, art.8, translated in (Japanese Law Translation [JLT DS]), http://www.japaneselawtranslation.go.jp (Japan); Foreign States Immunity Act 87 of 1981 § 4 (S. Afr.); State Immunity Act, R.S.C. 1985, c S-18 (Can.); Foreign States Immunities Act 1985 s 11 (Austl.); O yurisdiktsionnykh immunitetakh inostrannogo gosudarstva i sobstvennosti inostrannogo gosudarstva v Rossiyskoy Federatsii [The Federal Law on Jurisdictional Immunity of a Foreign State and a Foreign State's Property in the Russian Federation], art.7.
} 
in force, as well as the first years of the Turkish Republic and the period preceding the enactment of the law that adopted the restrictive doctrine: The International Private and Civil Procedure Law of 1982 numbered 2675. Further, after carefully examining various pieces of legislation, international agreements, and the decisions of the Court of Cassation before the entry into force of the International Private and Civil Procedure Law of 1982, Sections C and D highlight Turkey's historically strict adherence to the absolute doctrine that lasted until the early 1980s, and explain the political and economic atmosphere that prompted Turkey's switch to the restrictive doctrine.

In light of the findings in Section B, Section E examines the Turkish court decisions, particularly those issued by the Court of Cassation, identifying the ways in which Turkish State practice determines the private-law nature of a foreign State act. These identifications ultimately highlight the two aforementioned widely-used criteria throughout the court rulings to conclude that the Turkish caselaw has aligned itself with customary State practice in terms of which criteria is used to determine whether a State's act is of a private-law nature.

\section{B. Methods of Determining the "Private-Law" Nature}

Although the private-law or commercial nature of a foreign State act is enshrined as an exception to immunity by States that have adopted the restrictive doctrine, the criteria invoked to identify an act as having a private-law nature vary tremendously among States. Some States merely focus on the nature of the act to determine whether the act embodies a commercial or private-law character. ${ }^{4}$ Realizing the improbability of determining the nature of some acts without also considering their purpose, other States give deference to the sovereign purpose to which the act in question is intended to fulfill. ${ }^{5} \mathrm{All}$ in all, there is a growing convergence of State practice in the criteria used to determine the private-law nature of an act. The following subsections present the two widely-used criteria.

\section{The "Private Person" Criterion}

The most widely-used criterion for determining the private-law or jure gestionis character of an act is whether the act is the sort of action which a private person may equally perform. This criterion is predicated upon the rationale that a State performing an act of private-law nature places itself on equal footing with a private individual, and thus consents to consequences which could have materialized had the activity been performed by an

\footnotetext{
${ }^{4}$ ERnest K. Bankas, The State Immunity Controversy in International LaW: Private SuItS Against Sovereign States in DOMESTIC COURTS 75 (2005).

${ }^{5}$ XIAODONG YANG, STATE IMMUNITY IN INTERNATIONAL LAW 98 (2012).
} 
individual. ${ }^{6}$ It is worth noting that a private-law act need not be an activity a private person can engage in, but rather, the type of activity that when performed by a private person suffices for a grant of immunity. ${ }^{7}$ Under this criterion, the mere fact that a private person can equally perform the act in question in his private capacity qualifies the act as acta jure gestionis. ${ }^{8}$ For example, even though a contract concluded by a State envisages buying boots or even bullets exclusively for military purposes, it "is a 'commercial' activity, because private companies can similarly use sales contracts to acquire goods . . . ." Looking to specific applications by various courts in their decisions sheds further light on the issue and helps clarify the criterion.

Favoring the purpose test over the nature of the act test, British Courts came to the conviction that a State entering into the marketplace should be subject to the rules of the marketplace. In Trendtex Trading Corp. v. Central Bank of Nigeria, Lord Denning MR illustrated the reasoning behind denying immunity to a State performing a private-law act by referring to the theory that the State that does so essentially places itself on an equal footing with a private person:

[The contracts for cement to build barracks for the army] were like a contract of purchase of boots for the army. But I do not think this should affect the question of immunity. If a government department goes into the market places of the world and buys boots or cementas a commercial transaction-that government should be subject to all the rules of the market place. The seller is not concerned with the purpose to which the purchaser intends to put the goods. ${ }^{10}$

The U.S. Congress, in a legislative report, articulated similar reasoning:

[A] contract by a foreign government to buy provisions or equipment for its armed forces or to construct a government building constitutes a commercial activity. The same would be true of a contract to make repairs on an embassy building. Such contracts should be

\footnotetext{
${ }^{6} / d$. at 393.

${ }^{7} / d$. at 93.

${ }^{8}$ BANKAS, supra note 4 , at 74 .

${ }^{9}$ Republic of Argentina v. Weltover, Inc., 504 U.S. 607, 614 (1992).

${ }^{10}$ Trendtex Trading Corp. v. Central Bank of Nigeria, [1977] 2 WLR 356 at 370 (Eng.).
} 
considered to be commercial contracts, even if their ultimate object is to further a public function. ${ }^{11}$

The Supreme Court of the United States affirmed this approach of discarding purpose in commerciality discussion and contended that a State "engages in commercial activity ... . 'where it exercises only those powers that can also be exercised by private citizens,' as distinct from those 'powers peculiar to sovereigns."'12

In Controller and Auditor-General v. Sir Ronald Davison, the Court of Appeals of New Zealand denied immunity to the Government Auditor of the Cook Islands because the government had descended into the marketplace to such an extent as to buy and sell promissory notes integrally involved in tax credit transactions, and therefore could not fairly expect total immunity. ${ }^{13}$

In Republic of Argentina v. Weltover, Inc., the U.S. Supreme Court applied the same criterion in determining whether to grant immunity, and ruled that it was incumbent on courts to examine whether the particular state conduct is "the type of actions by which a private party engages in trade and traffic or commerce." ${ }^{\prime 4}$ There, the Court addressed the characterization of the act of issuing Argentinian government bonds to help stabilize its currency ${ }^{15}$ The Court found that the reason for Argentina participating in the bond market was irrelevant, and concluded that Argentina had acted in the manner of a private person. ${ }^{16}$

Comparatively, US courts have reached different conclusions with respect to contracts. In Practical Concepts, Inc. v. Republic of Bolivia, a U.S. corporation sued Bolivia for breach of contract. ${ }^{17}$ The district court focused on the contract's terms and held that Bolivia enjoyed immunity with respect to claims arising from the contract because the terms were such that only a sovereign state could perform-most notably a contractual agreement to grant preferential bureaucratic treatment alongside diplomatic privileges. ${ }^{18}$ The U.S. Court of Appeals for the District of Columbia Circuit, however, denied immunity on the grounds that

\footnotetext{
${ }^{11}$ INTERNATIONAL LAW REPORTS 272 (E. Lauterpacht \& C.J. Greenwood eds., 1994).

12 Saudi Arabia v. Nelson, 507 U.S. 349, 360 (1993) (citing Weltover, 504 U.S. at 614).

${ }^{13}$ Controller and Auditor-General v. Sir Ronald Davison [1996] 2 NZLR 278 (CA) at 288 (N.Z.).

${ }^{14}$ Weltover, 504 U.S. at 614.

${ }^{15} / d$. at 609 .

${ }^{16} / d$. at 615 .

${ }^{17}$ Practical Concepts, Inc. v. Republic of Bolivia, 615 F. Supp. 92 (D.D.C. 1985).

${ }^{18} / d$. at 93, 95.
} 
the aforementioned terms were "auxiliary," whereas the contract's core-the exchange of money for advice-was the "essence" which represented commercial action by a State. ${ }^{19}$

In Saudi Arabia v. Nelson, the U.S. Supreme Court further clarififyed the matter by focusing on the type of act that a private person cannot engage in. ${ }^{20}$ In its decision to extend immunity to Saudi Arabia for the conduct of its police forces, and despite highlighting the undoubtedly monstrous character of the treatment that the plaintiff endured, the Court stated that the "[e]xercise of the powers of police and penal officers is not the sort of action by which private parties can engage in commerce." ${ }^{21}$

In the same vein, a US District Court dismissed a claim arising out of tort inflicted by local thugs that various Chinese Ministrires had allegedly hired to intimidate the Falun Gong practitioners. The Court ruled the China's authority to hire thugs for implementing its policy of eradicating Falun Gong is "not of the nature that may be exercised by private citizens participating in the marketplace." ${ }^{22}$ Similarly, when Israel was sued for the actions it took pursuant to its settlement policy in the West Bank, the U.S. Supreme Court dismissed the case on the grounds that the Israeli activities did not constitute the type of activities in which private actors can engage in, as they were carried out by actors infused with the force and power of the Israeli government. ${ }^{23}$

In the preceding rulings, the non-private-law, or jure imperii, nature of the acts in question was determined by the conviction that they were disposed within the sovereign authority of the State or by officials empowered with the force of the State. With that in mind, the type of actions in which a private person cannot engage in his private capacity include expelling foreign nationals, seizing goods by police forces, issuing exchange controls, imposing and collecting navigation charges for flights over national airspace, drafting legislative acts, and executing international transactions. ${ }^{24}$

It is also worth noting that the type of activities that a private person cannot lawfully engage in customarily have not been characterized as the private-law acts of State. ${ }^{25}$ In this connection, kidnapping, money laundering, and political assassination have not received

\footnotetext{
${ }^{19}$ Practical Concepts, Inc. v. Republic of Bolivia, 811 F.2d 1543, 1548 (D.C. Cir. 1987).

${ }^{20}$ Saudi Arabia v. Nelson, 507 U.S. 349 (1993).

${ }^{21} / d$. at 362 .

22 Jin v. Ministry of State Security, 557 F. Supp. 2d 131, 141 (D.D.C. 2008).

${ }^{23}$ Doe I v. State of Israel, 400 F. Supp. 2d 86, 106 (D.D.C. 2005).

${ }^{24}$ YANG, supra note 5 , at 82.

${ }^{25}$ Fox \& WeBB, supra note 1 , at 278.
} 
qualification as private-law acts. This is not because private persons cannot perform them, but because private persons cannot do so through lawful means and because such illegal acts are not typically carried out in the market. ${ }^{26}$ By the same token, the U.S. Supreme Court's denial of immunity for Japan's use of its military to impose sexual slavery on the women of occupied Asia was predicated on the grounds that the conduct in question was not a lawful act typically carried out in the market. ${ }^{27}$ Comparatively, a Dutch court did not grant immunity to an individual for an agreement concluded between him and an undercover German police officer disguised as a drug dealer. ${ }^{28}$ The Dutch court reached its decision on the basis that private persons are not allowed to "enter into a similar legal relationship in a similar way with similar consequences." ${ }^{29}$

Italy and Belgium are among the first countries whose courts distinguish private-law acts from acts of sovereign nature. ${ }^{30}$ The Italian Court of Cassation held in 1972 that State activities could not be immune from jurisdiction if they were conducted in the legal order of the forum State in a manner similar to that of a private citizen.${ }^{31}$ Likewise, Belgian courts used similar reasoning to promote the restrictive doctrine-that bringing proceedings against a foreign State for its acts resembling that of a private individual did not hamper the sovereign authority of the State..$^{32}$ In Sociéte anonyme Compagnie des chemins de fer Liégeois Limbourgeois v. Etat Néerlandais, the Belgian Court de Cassation articulated that a State's purchase of goods, engagement in commerce, and operation of public utility services were the type of activities that a private person could equally perform, and concluded that a State exercising a private right in these domains could be sued before Belgian courts. ${ }^{33}$ This method has shifted focus from the purpose for which a State carries out an activity to three distinct questions: (1) whether a private person can perform the activity, (2) whether the State places itself on the same level with a private person, and (3) whether the State faces a private person on a basis of equality. ${ }^{34}$

\footnotetext{
${ }^{26}$ YANG, supra note 5 , at 84.

${ }^{27}$ Hwang Geum Joo v. Japan, 172 F. Supp. 2d 52, 63 (D.D.C. 2001).

28 INTERNATIONAL LAW REPORTS, supra note 11, at 344.

${ }^{29} / d$.

${ }^{30}$ Fox \& WEBB, supra note 1 , at 151.

${ }^{31} / d$. at 152.

32 BANKAS, supra note 4 , at 70-71.

${ }^{33}$ Hof van Cassatie [Cass.] [Court of Cassation], PAS. 24 Dec. 1903, 1903-II-294 (Belg.).

${ }^{34}$ Fourth Report on Jurisdictional Immunities of States and Their Property, U.N. Doc A/CN.4/357 (1982), reprinted in [1982] 2 Y.B. Int'I L. Comm'n 199, 277, U.N. Doc. A/CN.4/SER.A/1982/Add.1 (Part 1); MALCOM N. SHAW, INTERNATIONAL LAW 629 (7th ed. 2014).
} 
Using the criterion described above within the context of tort law, the Austrian Supreme Court held that the U.S. could not plead immunity with respect to a claim arising out of a motor vehicle accident caused by the negligence of a U.S. Embassy driver. ${ }^{35}$ The Austrian Supreme Court concluded as much in reasoning that the public road was the sphere where private individuals and the U.S. faced on a basis of equality, and where there could not be any question of supremacy and subordination. ${ }^{36}$

\section{The Criterion of Incorporating "Purpose" in Determining Private-Law Nature}

A considerable number of domestic courts and international instruments give deference to the sovereign purpose of an act in determining its nature where courts find that the sovereign purpose is highly relevant for such a determination. ${ }^{37}$ Courts have invoked the purpose test especially in those cases where a domestic court feels obliged to delve into the public purpose an act serves in order to determine its private law nature.

The purpose test focuses on the question of whether an act serves a sovereign purpose. Its use in determining whether to grant immunity has diminished as States that have strayed from their traditional functions have become confined to matters involving the maintenance of public order and ensuring the defense of the country. ${ }^{38}$ Although an increasing number of States have abandoned the sovereign purpose argument, tipping the balance in favor of the private-law/commercial nature test, ${ }^{39}$ a drastically reduced form of the purpose test has nevertheless survived in some State practice and even in the UN Convention on State Immunity ${ }^{40}$ whose article $2(2)$ reads:

In determining whether a contract or transaction is a "commercial transaction"... reference should be made primarily to the nature of the contract or transaction, but its purpose should also be taken into account if the parties to the contract or transaction have so agreed, or if, in the practice of the State of the forum, that purpose

\footnotetext{
${ }^{35}$ Oberster Gerichtshof [OGH] [Supreme Court] Feb. 10, 1961, Holubek v. The Government of the United States (Austria).

${ }^{36} / d$.

${ }^{37}$ YANG, supra note 5 , at 102

38 INTERNATIONAL LAW REPORTS, supra note 11, at 9.

${ }^{39}$ Pierre-Hugues Verdier \& Erik Voeten, How Does Customary International Law Change? The Case of State Immunity, 59 INT'L STUD. Q. 214 (2015).

40 The Un Convention on Jurisdictional Immunities of States And Their Property: A CommentaRy 191 (Roger O’Keefe \& Christian J. Tams eds., 2013).
} 
is relevant to determining the non-commercial character of the contract or transaction. ${ }^{41}$

The Canadian court practice represents a pattern where purpose is occasionally invoked to ascertain the private-law nature of an act, despite a clear provision of the Canadian State Immunity Act (Canadian SIA) stipulating that the commerciality of an act is to be determined by its nature..$^{42}$ In Re Canada Labour Code, the Canadian Supreme Court concluded that the aforesaid provision of the Canadian SIA did not preclude consideration of the purpose of an act, acknowledging the highly intertwined relation between nature and purpose alongside the difficulty of determining, in some instances, the former without giving regard to the latter. ${ }^{43}$ More importantly, stressing the importance of appreciating the entire context of an activity, the Canadian Supreme Court reasoned that "when an activity is multifaceted in nature, consideration of its purpose will assist in determining which facets are truly related to the proceedings in issue." 44

Similarly, the Italian Court de Cassation found it pertinent to inquire, while identifying the exact nature of an activity, whether the activity was intended to achieve public and institutional ends. In that regard, as opposed to the Weltover ruling pronounced by the U.S. Supreme Court, after establishing the private-law nature of issuing bonds, the Italian Court granted immunity to Argentina for unilaterally extending the payment time on the bonds, reasoning that the subsequent rescheduling of Argentina's obligation to honor the bonds served sovereign purposes and thus bore a sovereign character. ${ }^{45}$

In a similar vein, the French Court de Cassation applied the purpose test while examining the nature of an activity, and ruled that a contract for a commercial lease of premises pursued purely for a profit motive, would not entitle a defendant State to immunity. ${ }^{46}$

In Littrel v. USA, the British Court of Appeals addressed a claim for damages for personal injuries allegedly caused by medical treatment at a U.S. Air Force hospital in the United Kingdom. In its decision, the British Court of Appeals took into consideration (1) who carried out the typical activity that allegedly caused the damage, and (2) of what type the nature of

\footnotetext{
41 United Nations Convention on Jurisdictional Immunities of States and Their Property art. 2(2), Dec. 2, 2004, U.N. Doc. A/59/508.

42 State Immunity Act, R.S.C. 1985, c S-18 (Can.) (“[C]ommercial activity means any particular transaction, act or conduct or any regular course of conduct that by reason of its nature is of a commercial character.").

${ }^{43}$ Re Canada Labour Code, [1992] 2 S.C.R. 50 (Can.).

${ }^{44}$ Id.

${ }^{45}$ Fox \& WEBB, supra note 1 , at 261.

${ }^{46}$ YANG, supra note 5, at 103.
} 
the activity was. The British Court of Appeals then inquired into the nature of the activity of operating a hospital and concluded that it was a private-law act. Nonetheless, focusing on the sovereign purpose served by running a military hospital, the Court found the activity as jure imperii and dismissed the case on the basis of immunity. ${ }^{47}$

Comparatively, in its assessment of the private law nature of a lease agreement signed by the Consulate General of Nigeria on behalf of its employees, the United States Court of Appeals for the Ninth Circuit found it relevant to inquire whether the agreement was undertaken for the purpose of profit. The Court ruled that, even absent a profit motive, the lease agreement was a private-law transaction. ${ }^{48}$

Purpose and profit motive were again invoked within the application of the nature test in a case before the United States District Court for the District of Oregon. There, the District Court first drew an analogy between the guidance, education, and counseling services provided by the Holy See and those provided by private actors, pointing out the plausibility of characterizing the former as a type of private-law activity. ${ }^{49}$ Nevertheless, the District Court cautioned that the omission of purpose in such an evaluation would result in a superficial application of the nature test. The District Court thus concluded that the aforementioned "core religious duties" of the Holy See made purpose and motive highly relevant in the evaluation of the activities' nature. ${ }^{50}$

While concluding that South Africa's issuance of a press release claiming that the right to own the "southafrica.com" domain name was a non-commercial act, the U.S. Supreme Court delved into the question of whether the government had a profit motive in issuing the press release. The Court came to the realization that South Africa had done so as the regulator of the market rather than a participant in the market, and thus the Court concluded that the act's purpose was so highly relevant to its analysis that it outweighed the private-law nature of the act of operating in the market in the manner of a private actor. ${ }^{51}$

Philippine State practice attaches priority to the nature of a foreign State act, but also takes the destined purpose of the act into consideration when determining its commerciality. In United States of America and Others v. Ruiz and de Guzman and Company, and despite acknowledging the precedence of the legal nature of a contract over the fact that it was

\footnotetext{
47 Littrell v. USA (NO.2) [1994] 4 All ER 203 at 209.

${ }^{48}$ Joseph v. Office of the Consulate Gen. of Nigeria, 830 F.2d 1018, 1022 (9th Cir. 1987).

${ }^{49}$ Doe v. Holy See, 434 F. Supp. 2d 925, 941 (D. Or. 2006).

${ }^{50} / d$. at 941.

${ }^{51}$ Virtual Countries, Inc. v. Republic of South Africa, 300 F.3d 230, 241 (2d Cir. 2002).
} 
signed by a sovereign, the Philippine Supreme Court granted immunity for the following reason:

\begin{abstract}
A State may be said to have descended to the level of an individual and can thus be deemed to have tacitly given its consent to be sued only when it enters into business contracts. It does not apply where the contract relates to the exercise of its sovereign functions. In this case the projects are an integral part of the naval base which is devoted to the defense of both the United States and the Philippines, indisputably a function of the government of the highest order; they are not utilized for nor dedicated to commercial or business purposes. ${ }^{52}$
\end{abstract}

Whether to incorporate purpose as a determinative factor in the assessment of commerciality had long been a subject of debate in International Law Commission (ILC) meetings. Under Article 12 of the Draft Articles for a Convention on State Immunity proposed in the Fourth Report of 1982, the ILC set forth the rule: "[A] State is not immune from jurisdiction of another State in respect of proceedings relating to any trading or commercial activity conducted by it[]," thus envisaging an interpretive provision which suggested that the nature of the transaction rather than the purpose must be applied to determine its commerciality. ${ }^{53}$ Following criticism by many States, this proposal was weakened, leading to the $1986 \mathrm{draft}$ and the final $1991 \mathrm{draft}$ which provided: "Reference shall be made primarily to the nature of the transaction, but the purpose of that transaction shall also be taken into account if, in the practice of that State, that purpose is relevant to determining the non-commercial character of the contract." ${ }^{154}$ Apart from some varied and limitied support for the proposal, Germany, Norway, Sweden, Finland, Denmark, Iceland, the UK, Mexico, Spain, and Qatar opposed the incorporation of purpose as determinative of commerciality. ${ }^{55}$ The 1999 draft proposed deleting all references to the nature and purpose of the transaction because of the disagreements as to which test should prevail. Opting for

\footnotetext{
52 United States of America v. Ruiz, G.R. No. L-35645 (S.C., May 22, 1985) (Phil.).

${ }^{53}$ Fourth Report on Jurisdictional Immunities of States and Their Property, U.N. Doc A/CN.4/357 (1982), reprinted in [1982] 2 Y.B. Int'I L. Comm'n 199, 228, U.N. Doc. A/CN.4/SER.A/1982/Add.1 (Part 1).
}

${ }^{54}$ Eigth Report on Jurisdictional Immunities of States and Their Property, U.N. Doc A/CN.4/396 (1986), reprinted in [1986] 2 Y.B. Int'I L. Comm'n 21 at 24, U.N. Doc. A/CN.4/SER.A/1986/Add.1 (Part 1). Please note that Article 2(2) of the UN Convention on State Immunity retains the proposal listed in the $1991 \mathrm{draft}$.

${ }^{55} \mathrm{Id}$. at 51 . Yugoslavia supported the proposal without reservation, while Canada and Brazil supported the proposal with some reservations. 
the adoption of the highly recognized nature test, some states pushed back, arguing that courts or practitioners would lack guidance if there was no reference to either test. ${ }^{56}$

\section{The Evolution of State Immunity in Turkish History}

By virtue of the capitulations assigned to some European States, nationals of those States were exempted from Ottoman jurisdiction with regard to legal matters before a criminal court or court of law during the Ottoman era, regardless of the doctrines relating to exercising jurisdiction over a foreign State. ${ }^{57}$ The capitulations of the Ottoman Empire were grants made by successive Sultans to European powers, particularly France, conferring rights and privileges in favor of their subjects residing or trading in the Ottoman dominions. Accordingly, a foreigner was subject to the jurisdiction of the consular tribunal of his nationality and to the law of the nationality of the State to which capitulations were granted..$^{58}$ Thus, it is not plausible to advance that the Ottoman Empire could exercise jurisdiction over a foreign State in a jurisdictional system where the former could not adjudicate the latter's subjects before its domestic courts. Although the capitulations were formally abrogated in 1914 by a unilateral decree, it was not until the signature of the 1923 Treaty of Lausanne that the consular tribunals ceased their judicial function. ${ }^{59}$

The legal lacunae generated by the abolition of the capitulation was filled by the 1915 Interim Law on the Responsibilities of, and the Law Applicable to, Foreigners Resident in the Ottoman Dominions, ${ }^{60}$ under which judges dealt with matters related to immunity from execution. It remained in force until the enactment of the 1982 International Private and Civil Procedure Law numbered 2675 Law (the 1982 Law), the details of which are dealt with in the next sections.

By surveying the Turkish court practice before the 1982 Law, one observes the strict adherence to the absolute immunity doctrine throughout the court decisions. Among those decisions is a 1950 ruling by the Turkish Court of Cassation where it granted immunity to

\footnotetext{
${ }^{56}$ United Nations, General Assembly Sixth Committee, Fifty-Fourth Session, Convention on Jurisdictional Immunities of States and Their Property: Rep. of the Chairman of the Working Group q20, U.N. Doc. A/C.6/54/L.12 (Nov. 12, 1999).

57 COŞKUN ÜÇOK ET AL., TÜRK HUKUK TARIHI [HISTORY OF TURKISH LAW] 203 (1996).

${ }^{58}$ Gül Akyılmaz, Osmanlı Hukukundaki Düzenlemeler Çerçevesinde Yabancı Ülke Vatandaşlığına Geçen Ermenilerin Gayrimenkullerinin Hukuki Statüsü [The Legal Status of the Real Estates of the Armenians who Became Foreign Citizenship in the Framework of the Regulations in the Ottoman Law] 60/2014 YENI TÜRKIYE 1, 19 (2014).

$59 / d$.

${ }^{60}$ This law's Ottoman Turkish name is "Memaliki Osmaniyede Bulunan Ecnebilerin Hukuk ve Vezayifi Hakkında Kanun-I Muvakkat." This law regulates the law applicable to foreign residents, but lacks any provision governing immunity from jurisdiction applied to a foreign State.
} 
India for an agreement to purchase a thermal spring. In its reasoning, moving aside the blatant private-law nature of the purchase agreement, the court concluded that the State could not be the subject of adjudication because it had not consented or submitted to the jurisdiction of the Turkish courts. ${ }^{61}$

Likewise, in a case in which the U.S. was sued for its alleged infringement of a construction contract, the Court of Cassation granted immunity on the basis of the absolute rule, adducing that the Turkish courts cannot exercise jurisdiction over a foreign State unless (1) there is an explicit agreement between the respective States which provides so, or (2) the foreign State explicitly acquiesces to the other's jurisdiction. The Court of Cassation goes on to say that the question of whether to try a foreign State must otherwise be resolved under the principles of the Law of Nations, which obligate a forum State to not exercise any jurisdiction whatsoever over a foreign State. ${ }^{62}$

Other subject matters - which would have induced the Court of Cassation to deny immunity, had they been filed after the 1982 Law-include an action for debt arising out of a rental agreement between a leaser and the Chilean Embassy; ${ }^{63}$ an action for debt arising out of an employment relationship between the Personnel Directorate of the American Air Forces and its employee; ${ }^{64}$ a claim for damage for a traffic accident caused by a Bulgarian consular car; ${ }^{65}$ and an action for debt arising out of an employment relationship between the U.S. Military Office Club and its cook. ${ }^{66}$

\section{Enactment of the 1982 International Private and Civil Procedure Law}

Turkey witnessed fundamental social and economic changes with the administrations that came into office in the 1980 s and began promoting liberal policies in the economic and legal systems of Turkey. Turkey transitioned from a closed and controlled economy to one where markets played a major role in allocating resources. ${ }^{67}$ During this period, Turkey adopted a comprehensive package that, inter alia, allowed for flexible exchange rates, maintained

\footnotetext{
${ }^{61}$ Docket No: 1950/5402, Decree No: 1950/506481 (Turk.).

62 Docket No: 1968/630, Decree No: 1968/9285 (Turk.).

63 Docket No: 1955/5402, Decree No: 1955/415183 (Turk.).

${ }^{64}$ Docket No: 1964/3816, Decree No: 1964/375184 (Turk.).

${ }^{65}$ Docket No: 1979/6137, Decree No: 1979/1787 (Turk.).

${ }^{66}$ Docket No: 1964/7501, Decree No: 1964/8902 (Turk.).

${ }^{67}$ For a more elaborate explanation on the liberal orientation of Turkey during the 1980s, see izak Atiyas, Economic Institutions and Institutional Change in Turkey During the Neoliberal Era, 47 NEW PERSP. ON TURK. 57 (2012).
} 
positive real interest rates, removed barriers to international trade and finance, eliminated a number of restrictions on the banking system, and liberalized domestic markets. ${ }^{68}$

Against this backdrop, Turkey's government enacted several bills and decrees having the force of law that ensured the smooth implementation of the aforementioned marketoriented reforms, re-regulated the banking system, and governed over the privatization process many public institutions underwent. Under this political and economic climate, the Turkish Parliament ratified the 1982 Law, namely the International Private and Civil Procedure Law numbered 2675, which provides:

Both economic and social changes have inevitably brought about the advent of our international relations. Particularly emigration movements that took place after 1950's have posed many challenges, rendering thus the five-item Provisional Law incapable of dealing with the conflict of laws issue with respect of international conventions to which Turkey is a party since only item four addresses the issues as to the conflict of laws and the jurisprudence of Turkish courts. As a result of the compelling circumstances, the present draft has been drawn up with a view to rearranging the rules on this matter. Bearing in mind the international practice alongside the facts facing Turkey, legislation of foreign State the reports produced by the Hague Conference on Private International Law, International Commission on Civil Status, as well as conventions adopted by organizations such as the Council of Europe and the United Nations have been given regard in the drafting process of this law to ensure its alignment with international practice. ${ }^{69}$

The 1982 Law was abrogated in 2007 by the Act on Private International and Procedural Law numbered 5718 (the 2007 Law), whose Article 49 has retained the same provision relating to immunity. Article 49 of the 2007 Law provides:"A foreign [S]tate may not claim immunity from jurisdiction in legal disputes arising out of private law relations[,]" thus distinguishing an act falling within the context of acta jure gestionis from that of acta jure imperii. The reasoning of Article 33 of the 2007 Law was also retained in Article 49 of the 2007 Law, which provides: "The article envisages that a foreign State shall not enjoy immunity from

\footnotetext{
68 Metin Heper, The State and Debureaucratization: The Case of Turkey, 42 INT'L Soc. SCI. J. 605, 609 (1990).

69 Letter numbered 3737 of the Directorate General For Laws And Decrees of the Prime Ministry (Başbakanlık Kanunlar ve Kararlar Genel Müdürlüğü) entitled "General Reasoning /Genel Gerekçe”
} 
jurisdiction for its private law acts conducted in a manner of a private person, excluding the ones within the exercise of sovereign rights." ${ }^{\prime 70}$

Here, it is worthwhile to touch upon some compelling circumstances and policy considerations, which appear to have been influential in codifying the restrictive doctrine within the 1982 Law. At the outset, this change in Turkish legislation has dramatically influenced how the Turkish courts have dealt with the ratification of the immunity matter, with the aim of keeping up with the pertaining developments on international fora, as the 1982 Law's reasoning suggests. This appears to be an overdue change for a country like Turkey, whose legal system has traditionally identified with the European Continental lawthe European members of which have long embraced the restrictive immunity doctrine in their legislation and/or court practice.

More importantly, as Turkey implements comprehensive economic reforms-such as liberalizing its markets and removing the barriers to international trade and finance in an effort to attract investments and boost exports-maintaining the absolute doctrine would be counter-productive to the efficient operation of its markets. This is because it would not be fair to expect a party to engage in business with another party that cannot be brought before the courts of the the first party-namely, a State-which, in turn, would also be inconvenient for the State. ${ }^{71}$

Lastly, having transitioned from a closed and controlled economy into one in which private actors have major role in the markets, Turkey has come to acknowledge the liberal truism ${ }^{72}$ that the typical acts being performed in markets are those of private actors, and that a State operating in markets descends into a position that private actors ordinarily fill. Turkey has articulated this acknowledgement in the reasoning of Article 49, which acknowledges the truism by recognizing the fact that a State can engage in private law relations..

\section{E. The Turkish Court Practice After the Enactment of the 1982 Law}

The Turkish legal system, which has been wholly integrated with European Civil-law-also referred to as the Continental law-has long followed the legislation and jurisprudence of

\footnotetext{
70 Danışma Meclisi, Milletlerarası Özel Hukuk ve Usul Hukuku Hakkında Kanun Tasarısı Adalet Komisyonu Raporu [Report of the Draft Law on International Private Law and Procedural Law and Justice Commission], 100 S. SAYISI 10 madde 33 (1981).

${ }^{71}$ FOX \& WEBB, supra note 1, at 514.

72 YANG, supra note 5, at 63.
} 
Europe in its respective law branches. ${ }^{73}$ As a western-oriented country, a signatory to the European Convention on Human Rights, and a candidate for accession to the European Union, Turkey has been inspired by many principles on which Europe stands, and has thus strived to align its human rights jurisprudence with that of Europe. With this in mind, one may plausibly advance that Turkey, by and large, has been influenced by the trend tilting toward the restrictive immunity doctrine.

It was not until 1982, when the subsequently-repealed 1982 Law was enacted, that the Turkish Court of Cassation abandoned its strict observance of the absolute immunity doctrine in its rulings. Article 33 of the 1982 Law provided: "A foreign [S]tate may not claim immunity from jurisdiction in legal disputes arising out of private law relations." This language was retained in Article 49 of the subsequently-enacted 2007 Law.

Unlike the corresponding articles in the Canadian $\mathrm{SIA}^{74}$, the United States Foreign Soverign Immunities Act (the US FSIA), ${ }^{75}$ or the Australian Foreign States Immunities Act 1985 (the Australian FSIA), ${ }^{76}$ beyond the simple truism that private-law interactions do not give rise to a claim of immunity from jurisdiction, Article 49 of the subsequently-enacted 2007 Law does not provide which interaction is of a private-law nature, leaving a significant latitude for courts with regard to how the private-law nature is determined. In this respect, the Turkish Court of Cassation tends to identify an act as having a private-law character according to its nature, purposefully or coincidently availing itself of the aforementioned criteria observed throughout customary State practice. This is to say that the Court of Cassation focuses on the nature of an act of a foreign State and engages in an evaluation as to whether the act is of a kind that a private person could equally carry out. Yet, the fact that Turkish court practice takes notice of the nature of an act does not preclude the Turkish Court of Cassation from further taking into account an act's purpose, as doing so is relevant and useful in ascertaining the private-law or commercial nature of the act in question. Judging from the case law on immunity, it is worth noting that the Turkish caselaw has aligned with the customary State practice in terms of the criteria used to determine whether a State act is of a private-law nature.

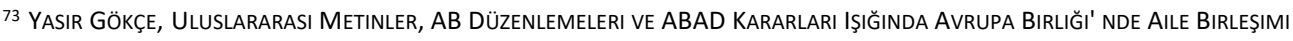
[FAMILY REUNIFICATION IN THE EUROPEAN UNION IN THE LIGHT OF INTERNATIONAL TEXTS, EU REGULATIONS AND ECJ RESOLUTIONS] 112 (2013)

74 State Immunity Act, R.S.C. 1985, c S-18, art. 2 ("[C]ommercial activity means any particular transaction, act or conduct or any regular course of conduct that by reason of its nature is of a commercial character.") (Can.).

7528 U.S.C. § 1603 (d) (“[A] commercial activity means either a regular course of commercial conduct or a particular commercial transaction or act.").

${ }^{76}$ Foreign States Immunities Act 1985 s 11(3) (“[C]ommercial transaction means a commercial, trading, business, professional or industrial or like transaction into which the foreign State has entered or a like activity in which the State has engaged.") (Austl.).
} 
The subsequent subsections examine the criteria that Turkish courts uses in working through the issue of the private-law characterization.

\section{The Act-Performed-in-the-Same-Manner-of-a-Private-Person Criterion in Turkish Court Practice}

Having tilted toward the restrictive doctrine since the enactment of the 1982 Law, the Turkish court practice has gone on to employ the act-performed-in-the-same-manner-of-aprivate-person criterion in decisions that deal with the immunity question. The Turkish Court of Cassation, which adopted a strict observance of the absolute immunity doctrine before the enactment of 1982 Law, was quick to embrace the restrictive doctrine by utilizing the ways commonly resorted to for determining the jure gestionis character of an act. ${ }^{77}$ That being said, a great number of rulings exist where the Turkish Court inquired into whether the act in question was among those types of acts that a private person could equally perform, granting or denying immunity accordingly. All in all, one should note that a salient convergence appears between the customary State practice and the Turkish practice in terms of the criterion used to identify whether an act has a private-law nature.

A decision published two years after the enactment of the 1982 Law reflected the confusion the Court of Cassation had in distinguishing State immunity from diplomatic immunity. In one case before the 12th Civil Chamber of the Court of Cassation, one party launced a lawsuit and execution proceedings against a vice consul's wife for her non-payment of rent. The Court used the state immunity mechanism laid out in Article 33 of the 1982 law to determine whether she enjoyed immunity, when it should have instead delved into the Vienna Convention on Consular Relations to resolve the issue. After citing Article 33 of the 1982 Law, the Court went on to say: "This article has made it clear that one can sue, and thereby serve notification on, a diplomatic representative who acquiesces to incur a debt arising out of a contract or of any other debt-breeding private-law transaction he concludes." ${ }^{78}$

In a case eventually brought before the Court of Cassation, a plaintiff sued the Iraqi government for damages arising out of its assault by jet fighters on his merchant ship as it navigated through the Persian Gulf. The assault resulted in the killing of three crew members and extensive damage to its oil tankers. After summarily explaining the current trends regarding State immunity and underlining the emphasis on "private-law relations" of Article

\footnotetext{
${ }_{77}$ Rona Aybay, Yargıtay Içtihatlarına Göre Yabancı Devletin Yargı Bağışıklığı [Judicial Immunity of the Foreign State by the Court of Appeals of the Court of Cassation], 72 TBBD DERGISI 110 (2007); Yasir Gökçe, Mutlak Yargı Bağışıkığından Sınırı Yargı Bağışıkı̆ğına Geçiş Trendi, iş Hukukundan Doğan Uyuşmazlıklarda Yargı Bağışıklığı ve Ülkemizdeki Durum [Transition Trend from Absolute Sovereign Immunity to Restrictive Sovereign Immunity, Sovereign Immunity in Disputes Stemming from Labor Law and the Situation in Turkey], 1 GAZI ÜNIVERSITESI HUKUK FAKÜLTESI DERGıSı 91, 93 (2014); Füsun Arsava, Yabancı Mahkeme Kararlarının Icrası ve Devletlerin Yargı Bağışıklı̆̆ı [Enforcement of Foreign Court Decisions and Judicial Immunity of States], 8 TAAD 1, 5 (2012).

${ }^{78}$ Docket No: 1984/8401, Decree No: 1984/11313 (Turk.).
} 
33 of the repealed 1982 Law, the Fourth Civil Chamber of the Court of Cassation inquired into whether the Iraqi government's conduct could qualify as a "private-law relation." The Fourth Civil Chamber concluded that it was an act of sovereign nature upon noting that that sort of engagement did not typically happen in relations between private actors:

Article 33 of the said Law stipulates that a foreign State may not claim immunity from jurisdiction in legal disputes arising out of private law relations. It is entailed, in the case at hand, to determine whether a tort resulting from an armed assault of war planes can be categorized as a "private-law relation." Depending on the conditions of a concrete case, damage done by war planes belonging to one of the belligerent States against a national of a third State obviously does not stem from a "private-law relation," instead is within the exercise of sovereignty. ${ }^{79}$

In a similar case involving a collision between a Turkish assault boat and a Soviet warship that resulted in the death of a naval non-commissioned officer, the Fourth Civil Chamber of the Court of Cassation held that, because the collision between the boat and warship did not represent a type of private-law relation defined in Article 33 of the 1982 Law, the then Soviet Union was to enjoy immunity in the matter. At the core of the Fourth Civil Chamber's reasoning, again, lied the criterion as to whether a State places itself on an equal footing with a private actor by engaging in a private-law relation:

What is meant by private relation in the article [33] is the disputes arising out of a State engaging in commercial relations and private activities in a similar manner of a private person. Otherwise, it would not be possible to opine that the activities disposed within the exercise of sovereign rights are among the private relations described in the article. The private-law relation described in the article should be ascertained under the Private International Law principles as well as legislative documents ... Whereas clearness of the legislative documents and historical development of International Law are for all to see, handling Private International Law matters with the concepts related to Private Law does not make any sense. ${ }^{80}$

\footnotetext{
79 Docket No: 1985/9190, Decree No: 1986/2436 (Turk.).

80 Docket No: 1987/7309, Decree No: 1987/7373 (Turk.).
} 
A dissenting judge embraced the exact opposite of the ruling advanced by the majority by using concepts of private law to handle the private international law matter. In doing so, he determined the private-law nature of the collision by referring to certain provisions of the Turkish Commerical Law:

Under article 822(2)-2 of the Turkish Commercial Law, public ships exclusively destined for public service and war planes belonging to the navy are also within the purview of article 947 and 948(1)-3 governing a freighter's responsibility for seaman's fault, as well as the provisions of the $4^{\text {th }}$ section related to collision, rescue and relief, and article 1326 laying out the restricted liability. Juxtaposing the two laws [the 1982 Law and the Turkish Commercial Law], I conclude that, as of [November 22, 1982,] Turkish law stipulates that liability of a warship belonging to the navy for damage arising from fault, which one of its seamen made in the course of his duty, is within the scope of Private Law, and that a State, therefore, do not enjoy immunity in a case where such a liability is claimed. ${ }^{81}$

Here, the dissenting judge infers the private-law nature of the collision from the fact that a private law institution, namely Turkish Commercial Law, covers the liability arising out of that type of conduct. In another dissenting opinion below, another judge for the Fourth Civil Chamber also predicated her dissent on a similar ground, noting that the collision between the assault boat and the foreign warship represented a private-law relation regulated by a private law institution:

What is meant by "private-law relation" in article 33 and under what law it is determined are of particular importance. Claims for damages arising from collision, a type of tort, are covered in the Turkish Commercial Law (articles 1216-1221). No doubt that those provisions constitutes Private Law norms. Given that the incident in the case occurred in the Turkish territorial waters and that obligations arising from torts shall be governed by the law of the country where the tortuous act was committed, the law applying to the case at hand is the provisions of the Turkish Commercial Law with related

${ }^{81}$ Esas Bakımından Karşı Oy Yazııı (II), Docket No: 1987/7309, Decree No: 1987/7373 (Turk.). 
to collision. What's more, though the provisions of the said Law with related to collision was put into force for commercial vessels, they are extended to warships and non-commercial vessels destined to public service, considering the latter has the same legal characteristics as the former(article $822(2)-2) .82$

Comparatively, the U.S. Consulate General was sued by its leasor for unpaid phone bills and misuse of the estate. The lawsuit and the question as to immunity was eventually brought before the Thirteenth Civil Chamber of the Court of Cassation. The Thirteenth Civil Chamber avoided a long-reasoned evaluation as to the nature of the lease agreement, presumed the "private-law" nature of the relation between the plaintiff and the U.S. Consulate, and accordingly reached the following conclusion that allowed the first incident court to proceed in its handling of the claim:

As can be inferred from the claim and the defense, the lease agreement is concluded between the plaintiff and the US Consulate. [Because] the Consulate represents the US, the relation is deemed to have forged between the plaintiff and the US ... [t] he lease agreement, which forms the basis of the case at hand, is a private-law transaction. The plaintiff claims damages for misuse of the property arising from the defendant's acts contrary to the contract, along with unpaid phone bills. Judging from qualification of the relation between the parties, the State in this case does not enjoy immunity from jurisdiction. Therefore, failure to proceed the case and to conclude it on the merits is unlawful and constitutes a ground for overturning the case. ${ }^{83}$

In the early 1990s, the General Assembly of Civil Chambers of the Court of Cassation, the highest judicial authority on civil matters in Turkey delved into the question of whether a lease agreement signed by the Lebanese embassy bore a private-law relation in light of the differences between State immunity and diplomatic immunities laid out in the Vienna Conventions. The General Assembly of Civil Chambers's brief touch upon the private-law-act exception to immunity in international law and its codification in the Turkish legal system is worth noting:

\footnotetext{
82 Esas Bakımından Karşı Oy Yazıı (III), Docket No: 1987/7309, Decree No: 1987/7373 (Turk.).

${ }^{83}$ Docket No: 1989/3896, Decree No: 1989/6648 (Turk.).
} 
It is not possible to accept the general immunity rule as absolute. States enjoy immunity from jurisdiction before domestic courts of a foreign State for acts in the exercise of sovereign authority, nevertheless not for the disputes arising from private-law relations, which are out of the scope of sovereign authority. Hence, the Law No. 2675 dated [November 23, 1982,] regulates the law applicable to private law transactions and relations that contain a foreign element, the international jurisdiction of the Turkish courts, and the recognition and enforcement of foreign judgments. Article 33 of the said Law blatantly enshrines that a foreign state may not claim immunity from jurisdiction in legal disputes arising out of private law relations and that, in such disputes, notifications may be served to diplomatic representatives of the foreign states .... Here, immunity to be accorded to a State engaging in a private law relation in a manner as a private actor ought to not be mistaken for immunity for diplomatic representatives. ${ }^{84}$

The Turkish Court of Cassation has, in some cases, presumed the private-law nature of a relation, reasoning that it was redundant to examine the nature of the conduct in question. The case against the Danish Embassy in Ankara that addressed an uninsured work period is a prime example of this. The Tenth Civil Chamber of the Court of Cassation, which tried the case as the appellate court, first concluded that the case against the Danish embassy was meant to be filed against the Kingdom of Denmark and that the plaintiff was considered to have worked for the Kingdom of Denmark. Then, referring to Article 33 of the 1982 Law, the Tenth Civil Chamber presumed the private-law nature of the employment relation between the plaintiff and the Kingdom without offering a reasoning for its conclusion. Interestingly, while explaining why Denmark did not enjoy immunity in this case, the Tenth Civil Chamber showed some humanitarian concerns with respect to the right to court access:

This is to say that, the embassy's defense that article 31 of the Vienna Convention applies in the case at hand, is inadmissible. A contemplation to the contrary would deprive Turkish nationals recruited by foreign embassies of the right to have legal remedy and redress. And this would be in contravention with human rights law and the relevant bylaws and regulations. This has become an

${ }^{84}$ Docket No: 1991/6-299, Decree No: 1991/406 (Turk.). 
established interpretation of the Court of Cassation, transforming into the actual practice. ${ }^{85}$

In another decision, which was brought all the way up to the Thirteenth Civil Chamber of the Court of Cassation, the Thirteenth Civil Chamber overturned the first incident court's decision not to proceed with the case on the grounds of the defendant's immunity. A portion of the cost for medication received by citizens of the Northern Republic of Turkish Cyprus (NRTC) was covered by pharmacies in Turkey to be reimbursed later by the NRTC under an agreement between Turkey and the NRTC. Upon the NRTC's failure to reimburse under the terms of the agreement, a pharmacist in Turkey commenced execution proceedings against the NRTC for payment, and then brought suit. The Appellate Court observed that the reimbursement was of a private-law character, despite arising from an agreement between two States. The relevant portion of the Court's decision is as follows:

In addition to conducting personal relations, a foreign embassy can carry out private transactions and conclude contracts on behalf of the State it represents, and the liability arising from these contracts is directly attributed to the State it represents. Lawsuits can be brought against an embassy representing a foreign State due to these sort of private-law contracts. This is to say, the NRTC embassy can be sued since it represents the NRTC .... The contract, which the plaintiff claims to exist and predicates on, is a private-law transaction. ${ }^{86}$

Further, in an action against the U.S. for its alleged violation of personal rights, the Fourth Civil Chamber of the Court of Cassation ruled in favor of an employee of a U.S. technical liaison office operating in Turkey. The employee filed a lawsuit for non-pecuniary damages arising from a violation of his personal rights on the basis that the liaison office had provided local authorities with baseless information that he had embezzled the office's money, thus causing the local authorities to bring charges against him. The Fourth Civil Chamber scrutinized the nature of the relation in question as follows:

State immunity, i.e. that a State cannot exercise jurisdiction over another State, is a principle predicated upon the equality among States. Indeed, it is a matter of fact that a State enjoy immunity for its conduct within the exercise of its sovereignty, and that the opinion that a State cannot be held liable in this matter, was

\footnotetext{
${ }^{85}$ Docket No: 1993/5620, Decree No: 1993/10875 (Turk.).

${ }^{86}$ Docket No: 2001/8947, Decree No: 2001/11405 (Turk.).
} 
prevalent. However, over time, the absolute immunity doctrine has been abandoned due to States engaging in private-law relations in the same manner of a private person. Thus, immunity is confined to sovereign acts ... . What is meant by private relation in the article [33] is the disputes arising out of a State engaging in commercial relations and private activities in a similar manner of a private person. Otherwise, it would not be possible to opine that the activities disposed within the exercise of sovereign rights are among the private relations described in the article. The private-law relation described in the article should be ascertained under the Private International Law principles as well as legislative documents.... It is alleged that the defendant had the plaintiff, particularly his private life, investigated by reporting to the authorities that he had embezzled money and thus had violated his personal rights. Accordingly, it is observed that the dispute in the matter emanates from a private-law relation, and that the trial should be examined on the merits since privatelaw relations do not give rise the immunity claim. ${ }^{87}$

Lastly, in a case for severance payment brought by a former security guard of the Japanese Embassy in Ankara against the embassy, the Ninth Civil Chamber of the Court of Cassation qualified the relation in question between the plaintiff and the embassy as being of a private-law character. The Ninth Civil Chamber held that Japan did not enjoy immunity with respect to the private-law relation in question, largely basing its judgment on the distinction between sovereign immunity and diplomatic immunity. ${ }^{88}$ Similarly, the Fourth Civil Chamber reversed the decision pronounced by a first incident court to not proceed with the case on the basis of immunity; the Fourth Civil Chamber categorized the injury arising out of an accident done by a diplomatic car belonging to the German Embassy as an "[A]rticle 33" relation that strips a State of immunity. ${ }^{89}$

As demonstrated by the aforementioned decisions of the Turkish Appellate Court, the widely-used criterion as to whether a State carried out an activity in the same manner of a private person also serves as a benchmark for the Turkish courts to determine whether an act falls within the "private-law" relation described in Article 49-the repealed Article 33. In

\footnotetext{
${ }^{87}$ Docket No: 2002/2431, Decree No: 2002/11163 (Turk.).

88 Docket No: 2009/913, Decree No: 2010/41802 (Turk.).

${ }^{89}$ Docket No: 2010/6451, Decree No: 2010/7394 (Turk.).
} 
that regard, the Turkish practice aligns with the current customary State practice in terms of the criteria by which the private-law nature of an act is characterized.

\section{The "Purpose-in-the-Private Law-Determination" Criterion in the Turkish Court Practice}

Parallelling the current customary State practice, the Turkish court practice has resorted to an act's "purpose" in determining whether the act is of a non-private-law nature and thus outside of the scope of Article $49 .{ }^{90}$ Nevertheless, contrary to the State practice where courts only use "purpose" when they find it highly relevant for a determination, the Turkish Court of Cassation tends to lay as much weight on the purpose of an act as it does on its nature. ${ }^{91}$ In other words, in Turkish practice, the criterion of whether the relation in question flows from an exercise of sovereign authority is as widely-used as the one described in the previous subsection. While current customary State practice indicates a trend towards only taking into account purpose when a court finds it relevant to determine whether an act is of a non-private law character, the Turkish practice seemingly differs from that trend in the sense that it more frequently considers purpose in such determinations.

The observation above also manifests itself in a decision of the Twelveth Civil Chamber of the Court of Cassation that examines an enforcement proceeding against bank accounts and aircrafts of Turkmenistan. Initially underlining the distinction between immunity from jurisdiction and immunity from execution, the Turkish Court dealt with the immunity question by emphasizing that consideration is given to both the nature and the purpose of a relation:

Immunity from jurisdiction and immunity from execution are different from one another. The nature and/or the purpose of a legal relation and transaction, the subject matter of the dispute, is given regard to resolve the immunity-from-jurisdiction question. On the other hand, while examining the dispute as to immunity from execution, one must take into consideration the essence of a property subject to the execution alongside the way it is used, rather than the relation underlying the dispute. ${ }^{92}$

\footnotetext{
${ }^{90}$ Yasir Gökçe, Trend Toward the Restrictive Doctrine of State Immunity: An Evaluation of This Trend in Respect of Employment Contracts, 6(11) L. \& J. REV. 181, 194 (2015).

${ }^{1}$ Id. at 195; Erdin Erdoğan, Yabancı Devletin Yargı Bağışıkığının Sınırları Hakkında Güncel Sorunlar ve Terör Suçları Açısından Yargı Bağışıklı̆ı [Current Problems about the Limits of Judicial Immunity in the Foreign State and Judicial Immunity in Terms of Terrorism], 65(4) ANKARA ÜNI. HUKUK FAK. DERGISI 3375, 3379 (2016).

${ }^{92}$ Docket No: 2004/6469, Decree No: 2004/13007 (Turk.).
} 
In a decision pronounced almost two years after the 1982 Law came into force, while mistaking diplomatic immunity for state immunity, the Court of Cassation found that Article 33 of the 1982 Law governing state immunity also applied to diplomatic immunity despite the existence of an international convention with the force of law governing the latternamely the Vienna Convention on Diplomatic Relations. The Sixth Civil Chamber's following statements are worth noting in that they inquire into whether the type of relation in question serves public interests:

Article 33 of the 1982 Law numbered 2675 envisages that a foreign State does not enjoy immunity in disputes arising from its private law relations. This article also encompasses diplomatic representatives. As stressed in the preamble of the Vienna Convention of Diplomatic Relations, the purpose of such privileges and immunities is not to benefit individuals but to ensure the efficient performance of the functions of diplomatic missions as representing States. There cannot be any mention of public interest in activities of diplomatic representatives within the full scope of private law, therefore jurisdictional immunities of diplomatic representatives need to be constrained to their duties related to the performance of the official functions. The defendant does not enjoy immunity in the matter at hand since the dispute has stemmed from a rental agreement. ${ }^{93}$

In the case discussed in the previous subsection involving a collision between a Turkish assault boat and a Soviet warship, the court provided the following reasoning for looking to the sovereign purpose as the dominant factor in making its final determination that immunity extended to the then Soviet Union, despite the Court's acknowledgment that the collision was governed by the relevant provisions of the Turkish Commerical Law:

It is obvious that a warship is the symbol of sovereignty of the state whose flag it flies. For this reason, warships enjoy immunity . . . In Comparative Law, even a State's purchase of arms for its armed forces was regarded as a sovereign act, for which the State enjoy immunity. Indeed, in its ruling dated January 23, 1933, the French Cour de Cassation granted immunity to the Afghan government for its purchase of equipment to be used by its armed forces. Because, notwithstanding purchase

${ }_{93}$ Docket No: 1984/3729, Decree No: 1984/5731 (Turk.). 
and sale of arms being a commercial transaction, that the Afghan government virtually engaged in a commercial activity is out of the question .... ${ }^{94}$

The Court of Cassation denied immunity to the U.S. in a dispute arising from its alleged non-payment of rent and misuse of property. While assessing the nature of the relation between the plaintiff and the State, the Sixth Civil Chamber took notice of the fact that the relation neither fulfilled nor facilitated the State's diplomatic function. The Sixth Civil Chamber's reasoning is especially worth noting in that it bolsters its conclusion that the act was of a private-law nature because the act did not serve sovereign purposes:

The premises, the subject matter of this case, is neither an embassy nor the ambassador's residence. It is leased to meet the need for accommodation of the employees working in the embassy .... In that connection, the dispute in the hereby case concerns the claims for damages and debt arising out of a lease agreementsubject to Private Law-between the leasor and the foreign State not entitled to immunity by virtue of the relation. There is nothing to stop the case from proceeding in terms of its diplomatic aspect or eligibility to be a party to the proceedings. ${ }^{95}$

In one case, the Court of Cassation granted immunity to Germany after inquiring whether a treaty between Turkey and Germany governing issuance of visas for workers made the visa procedures a private-law act. The Court oscillated between the private-law nature of employment contracts governed by the treaty and the sovereignty infused in the power of issuing or denying visas:

The dispute concerns whether Germany can be sued before the Turkish courts for its act in the form of granting or denying, via the German Consulate in Izmir, a visa application lodged under the "Treaty on Recruiting Employers of Turkish Companies within the Framework of Employment Contract" signed between Turkey and Germany, and whether the act is within the scope of the exercise of sovereign rights or relates to a civil dispute arising from a private-law relation within the scope article 49 of the 2007 Act. Visa, contingent upon the

\footnotetext{
${ }^{94}$ Docket No: 1987/7309, Decree No: 1987/7373 (internal citations omitted) (Turk.).

95 Docket No: 2009/10643, Decree No: 2009/10361 (Turk.).
} 
political agreements, is a permission attached to a passport or to the likes by Consulates of pertaining countries, which has to be shown while crossing border. It is no doubt under both international law and domestic law that procedures concerning visa are among transactions within the exercise of state sovereignty. In that connection, the acts in the form of rejecting a visa application or not taking it into evaluation ought to be assessed within the scope of sovereign acts .... The fact that the treaty between States governs the visa status of the workers to be recruited under the employment contract and the very treaty is breached, does not necessarily lead to the conclusion of the subject matter of the dispute being a private law transaction. ${ }^{96}$

\section{F. Conclusion}

The foreign state immunity doctrine is well established as a doctrine of customary international law. ${ }^{97}$ Under the law of State immunity, "the private-law act," also expressed in Latin terms as acta jure gestionis, refers to an exception to State immunity that serves as a determinative benchmark for the question of whether a State is subject to the jurisdiction of a foreign domestic court. ${ }^{98}$ Once a court establishes that an act is of a "private-law" nature, the tendency is to deny immunity to a foreign State. This leads to the necessity of identifiying the proper way of characterizing an act as having a private-law nature..

Although States with the restrictive doctrine have introduced their own commercial or private-law exceptions through legislation and caselaw, ${ }^{99}$ the methods of determining whether an act is of a private-law character vary from one State to another. Nevertheless, the most widely-used criteria for such a determination show a clear convergence of State practice in the ways that courts consider the question.

A combination of doctrinal and comparative analyses shows that one of the widely-used criterion is whether the act is a sort of action that a private person can equally perform. Under this criterion, the mere fact that a private person can equally perform the act in

\footnotetext{
${ }^{96}$ Docket No: 2013/10023, Decree No: 2013/13933 (Turk.).

${ }^{97}$ FOX \& WEBB, supra note 1 , at 13.

${ }^{98} / d$. at 413.

${ }^{99}$ See sources cited supra note 3.
} 
question in his private capacity qualifies the act as acta jure gestionis. ${ }^{100}$ Another widely-used criterion in customary State practice places an act's purpose at the heart of the discussion of the private-law characterization. Though not as frequently-used as the other, this criterion is incorporated into the assessment of private-law characterization when it is found that the purpose is highly relevant for such a characterization. ${ }^{101}$

As a western-oriented country, a signatory to the European Convention on Human Rights, and a candidate for accession to the European Union, Turkey was quick to embrace the restrictive doctrine and distill those criteria into its legal system after the enactment of the 1982 Law-Article 33 of which regulated the private-law exception to immunity. Having experienced a period during the Ottoman era where a foreign subject could be tried by a consular court of his nationality as per the capitulations granted to a number of foreign countries, ${ }^{102}$ Turkey strictly adhered to absolute immunity from 1923, which marks the proclamation of the Republic of Turkey, until the enactment of the International Private and Civil Procedure Law numbered 2675 in 1982.

Looking through the Turkish court practice related to State immunity, the Turkish courts focus on the nature of a State act and engage in an evaluation as to whether the act is of the kind that a private person could equally carry out. ${ }^{103}$ Interestingly, while the current customary State practice indicates a trend towards taking into account purpose where it is found relevant to determine the non-private-law character of an act, the Turkish practice seemingly differs from that trend as it more frequently considers purpose in such a determination. ${ }^{104}$ Generally speaking, the Turkish caselaw has aligned itself with the customary State practice in terms of the criteria used to determine a State act's private-law nature.

\footnotetext{
100 BANKAS, supra note 4 , at 74 .

101 YANG, supra note 5, at 102.

102 United States of America v. Ruiz, G.R. No. L-35645 (S.C., May 22, 1985) (Phil.).

${ }^{103}$ Meclisi, supra note 70.

104 See supra note 83 and accompanying text.
} 